UDC 342.4

LBC 67.400 .1

\title{
CONSTITUTIONAL BUILDING: THEORETICAL ASPECTS
}

\author{
Vahram R. Davtian \\ Volgograd State University, Volgograd, Russian Federation
}

Zigmund A. Stankevich

Kutafin Moscow State Law University, Moscow, Russian Federation

Introduction: the article deals with the term of constitutional building and its semantic content in the different periods of time in the scientific works of scientists and the modern perception. For this purpose, the author presents different points of view of the scientists regarding these definitions. By applying the scientific methods, the author defines the concept of constitutional building and distinguishes it from such categories in the field of constitutional law as a constitutional order and state-building.

Results: it is stated that it is allowed to identify the concept of constitutional form of government and political system. However, the difference may be due to the certain circumstances.

Conclusions: the author comes to the conclusion that constitutional building may be interpreted as the process of building a constitutional or political system. Meanwhile, we should not identify the concept of state-building and constitutional building, since state-building is often defined as the process of appearing specialized personnel, control over the joint territory, loyalty, and strength of political institutions with a centralized and autonomous position of holding the violence monopoly against the population of the state. Constitutional building acts as a way of organizing the state in which the state is subordinate to the rights and freedoms of man, regulated by the specific legal acts.

Key words: constitutional building, constitutional order, state system, state-building.

УДК 342.4

ББК 67.400 .1

\section{КОНСТИТУЦИОННОЕ СТРОИТЕЛЬСТВО: ТЕОРЕТИЧЕСКИЕ АСПЕКТЫ}

\author{
Ваграм Рафикович Давтян \\ Волгоградский государственный университет, г. Волгоград, Российская Федерация \\ Зигмунд Антонович Станкевич \\ Московский государственный юридический университет им. О.Е. Кутафина (МГЮА), \\ г. Москва, Российская Федерация
}

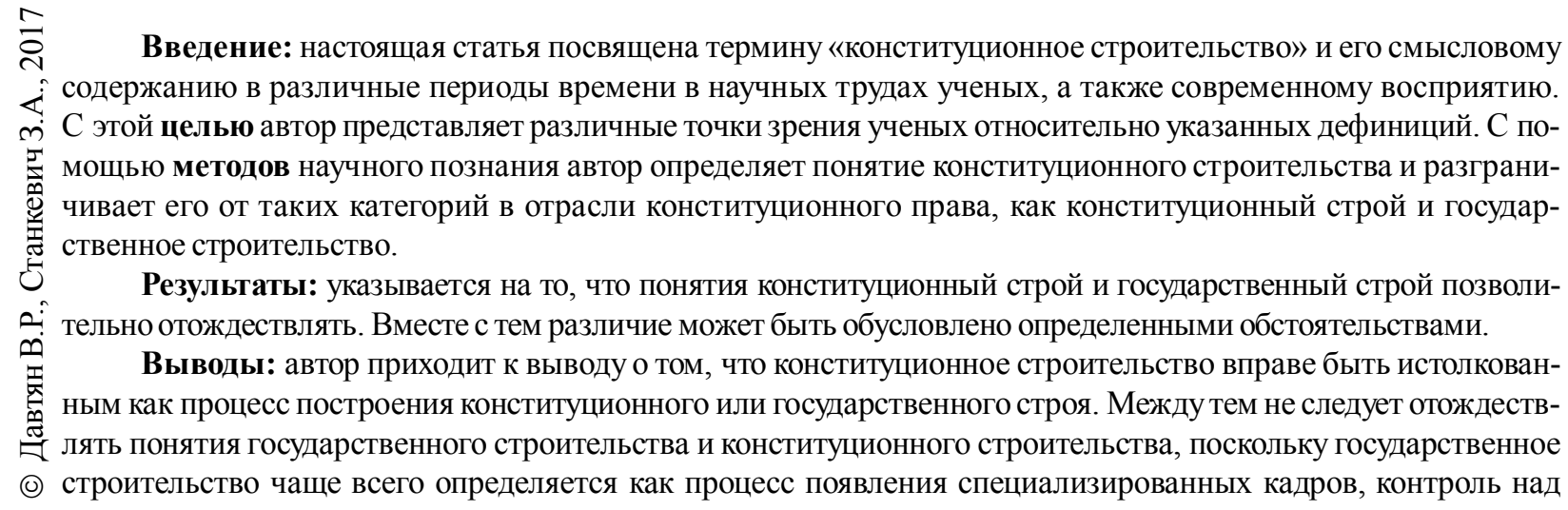




\section{ТЕОРИЯ И ПРАКТИКА ГОСУДАРСТВЕННО-ПРАВОВОГО РАЗВИТИЯ}

совместной территорией, лояльность и прочность политических институтов с централизованным и автономным положением, удерживающих монополию на насилие по отношению к населению данного государства. Конституционное строительство выступает как способ организации государства, при котором государство подчиняется правам и свободам человека, регламентированным в определенных нормативно-правовых актах.

Ключевые слова: конституционное строительство, конституционный строй, государственный строй, государственное строительство.

\section{Введение}

Многочисленные источники и литература свидетельствуют о том, что конституционное строительство представляется сложным и неоднозначным понятием. Как правило, конституционное строительство в самом общем виде определяют как процесс создания конституций на всем историческом развитии государства $[9$, с. 30], либо отождествляют его с процессом проектирования конституционного строя в государстве [10, с. 124], или смешивают со способом совершенствования общественно-политических систем государства [2, с. 76]. В этой связи приходится констатировать, что точное представление о сущности конституционного строительства в настоящее время отсутствует, а его содержание и смысловая нагрузка могут быть поставлены в зависимость от различных правовых и социальных явлений.

Между тем, учитывая потребность в целостном восприятии такого понятия, как конституционное строительство, необходимо обратиться к устоявшимся точкам зрения некоторых авторов.

Рассмотрим позиции ученых относительно понятий «конституционное строительство», «конституционный строй» и «государственный строй».

Так, американский ученый К. Сайнстейн в 2001 г. определил конституционное строительство как способ разрешения внутренних конфликтов (этнических, религиозных и т. д.), с помощью определенных гарантий прав человека, демократизации общества, а также привлечения максимально возможного числа участников в политическом процессе определенного государства [11, с. 239]. Очевидно, что подобная формулировка объясняется характерным стремлением развитых европейских государств и Соединенных Штатов Америки в частности внедрить демократизацию во все сферы общественной жизни.
В России годами ранее обосновывалась позиция, согласно которой конституционное строительство - это построение системы социальных, экономических, политико-правовых отношений, устанавливаемых и охраняемых конституцией и другими конституционно-правовыми актами [10, с. 126]. Примечательно, что данное определение имеет схожие черты с определением конституционного строя. Вместе с тем конституционный строй представляет собой систему социальных, экономических, политико-правовых отношений, устанавливаемых и охраняемых конституцией и другими конституционно-правовыми актами государства [8, с. 332]. Таким образом, конституционный строй определяется как явление в статике (невзирая на то, что в конституцию могут быть внесены определенные правовые нормы, изменяющие конституционный строй в целом). Конституционное строительство представляет собой явление в динамике, поскольку имеется в виду сам процесс построения, то есть перенос установленного конституцией конституционного строя на фактические общественно-политические отношения.

C.P. Чеджемов в авторской статье подразделяет данное понятие на две составные части: теоретическую и практическую. Теоретическая часть - это политико-правовые идеи и учения о праве и государстве, в том числе и об общих принципах конституционализма, а практическая часть - это непосредственно конституционное строительство [10, с. 125].

Вызывает также интерес и ретроспективный взгляд А.С. Смыкалина, который в своей научной работе определяет конституционное строительство в СССР как особую веху в истории отечественного конституционализма. Он также утверждает, что все советские конституции представляют собой взаимосвязанный процесс советского конституционного строительства [9, с. 32]. Это означает, что четыре конституции советской эпо- 
хи составляют конституционное строительство советского периода.

Учитывая изложенное, представляется возможным заключить, что применительно к Российской Федерации конституционное строительство должно подразумевать ряд предшествующих конституций советского периода, а также действующую Конституцию РФ.

При этом, если конституционное строительство, как уже было определено выше, это процесс построения конституционного строя, то позволителен ли вывод о том, что конституционное строительство может рассматриваться и как процесс построения государственного строя?

Государственный строй, по мнению В.В. Лазарева, - это совокупность общественно-политических отношений, выражающих наиболее принципиальные свойства, взаимосвязи и взаимодействия в механизме организации и функционирования государства. Помимо этого, автором указывается, что государственный строй является общим понятием, объединяющим суть, содержание и форму государства [6, с. 29].

Юридическая энциклопедия определяет понятие «государственный строй» через отраженные в конституции основы устройства общества и государства, характер политических отношений и организацию власти в данной стране, главные черты социальных и экономических отношений (в особенности формы собственности и организации хозяйствования), статус личности, внутреннюю структуру государства, систему органов государственной власти, а также основы местного самоуправления (если оно провозглашено в данном государстве).

Таким образом происходит отождествление понятий государственный строй и конституционный строй.

Вместе с тем следует обратить внимание на то, что государственный строй симметрично проектирует: 1) отношения между государством, обществом и личностью; 2) методы осуществления народовластия и государственной власти; 3 ) форму правления государства; 4) форму государственного устройства; 5) экономическую, политическую и идеологическую основы государства; 6) роль права и закона в организации и деятельности государ- ства $[6$, с. 28].Что касается понятия «конституционный строй», то оно обладает двумя сущностными характеристиками: 1) это способ организации государства - совокупность признаков, по которым одно государство можно отличить от другого (форма государственного устройства, форма правления, политический режим и др.); 2) это такой способ организации государства, который ставит его (государство) в подчинение интересам человека, его естественным правам и свободам через регламентирование деятельности государства правовыми ограничениями (где основную роль играет конституция), за рамки и пределы которых государство выходить не должно [4, с. 30].

Учитывая изложенное, следует, что конституционный строй - это система правовых отношений, закрепляющая способ организации государства, при котором признаются и гарантируются права и свободы человека и гражданина, а государство подчинено праву и, прежде всего, демократической Конституции [4, с. 29].

\section{Выводы}

Из выше рассмотренного можно сделать вывод, что понятия «конституционный строй» и «государственный строй» позволительно отождествлять. Вместе с тем различие может быть обусловлено определенными обстоятельствами, к примеру, наличием писанной конституции в каком-либо государстве и приданию ей высшего юридического значения либо ее отсутствием (в первом случае - это конституционный строй, а во втором - государственный строй). При этом приведенный пример не является уникальным.

Примечательно, что сравнение данных понятий напоминает компаративный анализ таких дефиниций как конституционное право и государственное право. Как объясняет М.В. Баглай, принципиальных отличий между выбором конституционного или государственного права нет, чаще всего это обусловлено традицией, устоявшейся в определенных государствах. Например, в США и во Франции используется термин «конституционное право», а в Германии тоже в демократическом правовом государстве - «государственное право» [1, с. 20]. 


\section{ТЕОРИЯ И ПРАКТИКА ГОСУДАРСТВЕННО-ПРАВОВОГО РАЗВИТИЯ}

Принимая во внимание изложенное, представляется возможным сделать вывод о том, что конституционное строительство вправе быть истолкованным как процесс построения конституционного или государственного строя. Признавая тождественность конституционного и государственного строя, следовало бы предположить возможность отождествления понятий государственного и конституционного строительства. Между тем, по нашему мнению, такое предположение было бы неверным, поскольку государственное строительство чаще всего определяется как процесс появления специализированных кадров, контроль над совместной территорией, лояльность и прочность политических институтов с централизованным и автономным положением, удерживающих монополию на насилие по отношению к населению данного государства [5, с. 1]. Конституционное строительство, как уже упоминалось ранее, выступает как способ организации государства, при котором государство подчиняется правам и свободам человека, регламентированным в определенных нормативно-правовых актах.

Будучи поставленным в зависимость от различных факторов (географических, социальных, политических и экономических), термин «конституционное строительство» справедливо определять через процесс проектирования основ конституционного строя на реальные фактические общественно-политические отношения. Помимо этого, конституционное строительство должно находиться в тесной взаимосвязи с основными принципами устройства государства, установленными в конституции, которые одновременно с их провозглашением должны являться непосредственно действующими в самом государстве.

\section{СПИСОК ЛИТЕРАТУРЫ}

1. Баглай, М. В. Конституционное право Российской Федерации : учеб. для вузов / М. В. Баглай. -6-е изд., изм. и доп. - М. : Норма, 2007. - 784 с.

2. Ваславский, Я. И. Конституционные условия для демократии. Сравнительный анализ : монография / Я. И. Ваславский ; Моск. гос. ин-т междунар. отношений (ун-т) МИД России, каф. сравнит. политологии. - М. : МГИМО - Университет, 2008. - 192 c.
3. Государственный строй // Энциклопедия Юриста. - Электрон. текстовые дан. - Режим доступа: http://eyu.sci-lib.com/article0000438.html. - Загл. с экрана.

4. Катков, Д. Б. Конституционное право России : учеб. пособие / отв. ред. академик РАЕН Ю. А. Веденеев ; Д. Б. Катков, Е. В. Корчиго. - М. : Юриспруденция, 1999. - 288 с.

5. Конституционный строй // Академик. - Электрон. текстовые дан. - Режим доступа: http://dic. academic.ru/dic.nsf/enc_law/1044. - Загл. с экрана.

6. Лазарев, В. В. Общая теория права и государства : учебник / под ред. В. В. Лазарева. - 3-е изд., перераб. и доп. - М. : Юристь, 2001. -520 с.

7. Робская, С. А. Государственное строительство как политический процесс (направления исследований) / С. А. Робская // Вестник Адыгейского государственного университета. Серия 1, Регионоведение: философия, история, социология, юриспруденция, политология, культурология. - 2012. № 2. - C. 223-228.

8. Румянцев, О. Г. Энциклопедия для юриста. / О. Г. Румянцев. - [Б.м.], 2005.

9. Смыкалин, А. С. Конституционное строительство России: Вехи истории / А. С. Смыкалин // Сайт Информационно-аналитического вестника Уральской академии государственной службы «Чиновник». - 2003. - № 6 (28). - Электрон. текстовые дан. - Режим доступа: http://law.edu.ru/doc/document. asp?docID=1150105). - Загл. с экрана.

10. Чеджемов, С. Р. Конституционное строительство в конце ХХ века в СССР и РФ: к проблеме суверенитета / С. Р Чеджемов. - Владикавказ : Изд-во Северо-Осетинского государственного ун-та им. К. Л. Хетагурова, 2010. - С. 124-130.

11. Sunstein, C. Designing democracy: What constitutions do / C. Sunstein. - N.Y. : Oxford University Press, 2001. $-239 \mathrm{p}$.

\section{REFERENCES}

1. Baglay M.V. Konstitutsionnoe pravo Rossiyskoy Federatsii [Constitutional Law of the Russian Federation]. Moscow, Norma Publ., 2007. 784 p.

2. Vaslavskiy Ya.I. Konstitutsionnye usloviya dlya demokratii. Sravnitelnyy analiz : monografiya [Constitutional Conditions for Democracy: Comparative Analysis. Monograph]. Moscow, MGIMO Publ., 2008. 192 p.

3. Gosudarstvennyy stroy [State Order]. Entsiklopediya Yurista [Lawyer's Encyclopedia]. URL: http://eyu.sci-lib.com/article0000438.html.

4. Katkov D.B. Konstitutsionnoe pravo Rossii [Constitutional Law of Russia]. Moscow, Yurisprudentsiya Publ., 1999. 288 p. 
5. Konstitutsionnyy stroy [Constitutional Order]. Akademik. URL: http://dic.academic.ru/dic.nsf/ enc_law/1044.

6. Lazarev V.V. Obshchaya teoriya prava $i$ gosudarstva: uchebnik [General theory of Law and State: Textbook]. Moscow, Yurist Publ., 2001. 520 p.

7. Robskaya S.A. Gosudarstvennoe stroitelstvo kak politicheskiy protsess (napravleniya issledovaniy) [State Construction as a Political Process (Research Directions)]. Vestnik Adygeyskogo gosudarstvennogo universiteta. Seriya 1, Regionovedenie: filosofiya, istoriya, sotsiologiya, yurisprudentsiya, politologiya, kulturologiya, 2012, no. 2, pp. 223-228.

8. Rumyantsev O.G. Entsiklopediya dlya yurista [Encyclopedia for Lawyers]. 2005.

9. Smykalin A.S. Konstitutsionnoe stroitelstvo Rossii: Vekhi istorii [Constitutional Construction in
Russia: Historical Landmarks]. Sayt Informatsionnoanaliticheskogo vestnika Uralskoy akademii gosudarstvennoy sluzhby "Chinovnik» [Website of Information and Analytical Journal of the Urals Academy of State Service "Official"], 2003, no. 6 (28). URL: http://law.edu.ru/doc/document.asp?docID= 1150105.

10. Chedzhemov S.R. Konstitutsionnoe stroitelstvo $v$ kontse XX veka v SSSR $i$ RF: $k$ probleme suvereniteta [Constitutional Construction in the End of the $20^{\text {th }}$ Century in the USSR and Russia: the Problem of Sovereignty]. Vladikavkaz, Izd-vo Severo-Osetinskogo gosudarstvennogo un-ta im. K. L. Khetagurova, 2010, pp. 124-130.

11. Sunstein C. Designing democracy: What constitutions do. New York, Oxford University Press, $2001.239 \mathrm{p}$.

\section{Information about the Authors}

Vahram R. Davtian, Candidate of Juridical Sciences, Associate Professor, Department of Constitutional and Municipal Law, Volgograd State University, Prosp. Universitetsky, 100, 400062 Volgograd, Russian Federation, davagram@yandex.ru.

Zigmund A. Stankevich, Doctor of Juridical Sciences, Kutafin Moscow State Law University, Sadovaya-Kudrinskaya St., 9, 125993 Moscow, Russian Federation, miussy-zs@yandex.ru.

\section{Информация об авторах}

Ваграм Рафикович Давтян, кандидат юридических наук, доцент кафедры конституционного и муниципального права, Волгоградский государственный университет, просп. Университетский, 100, 400062 г. Волгоград, Российская Федерация, davagram@yandex.ru.

Зигмунд Антонович Станкевич, доктор юридических наук, Московский государственный юридический университет им. О.Е. Кутафина (МГЮА), ул. Садовая-Кудринская, 9, 125993 г. Москва, Российская Федерация, miussy-zs@yandex.ru. 